Iványi Márton Pál: Egy látszólagos paradoxon:

a kereszténység fogalmainak arab szókészlete a máltai nyelvben

Argumentum 17 (2021), 878-894

Debreceni Egyetemi Kiadó

DOI: $10.34103 /$ ARGUMENTUM/2021/49

\title{
Tanulmány
}

\section{Iványi Márton Pál \\ Egy látszólagos paradoxon: a kereszténység fogalmainak arab szókészlete a máltai nyelvben}

\begin{abstract}
The Arab substratum of the words related to the fundamental cults of Christianity obviously reflect Arab origin. In spite of the Western rapprochement of the archipelago's population since the Norman invasion of the islands, the Maltese lexicon of Christianity's major concepts and rites has not changed significantly, while more complex and abstract terms have been adopted predominantly, although far from exclusively, from Indoeuropean (Sicilian/Italian) languages. This paper offers an overview of relevant historical and linguistic processes, highlighting some of the current hypotheses concerning the history of religions of Malta, juxtaposing a number of lexemes with their Modern Standard Arabic equivalents and Maghrebi dialectal variations. In addition, it is pointed out that relevant lexicon can be classified in a number of categories, such as: major metaphysical concepts, references of church institutions, words of religious practices, feasts, church tools and lexemes covering social life arguably inspired by either Christian or Muslim religion.
\end{abstract}

Keywords: Maltese, Christianity, Arabic, strata, lexicon

\section{Bevezetés}

A kortárs brit író Simon Scarrow magyarul is Kard és handzsár címmel megjelent történelmi regényének XIX. fejezetében olvasni, hogy Málta 1565-ös ostromának elökészületei közepette voltak néhányan, akik katonaként szolgálták a [máltai lovag-]rendet, ők segítették a kiképzőket és fordították le parancsaikat a helyiek nyelvére, ami inkább emlékeztetett az arabra, mint bármely európai nyelvre. Ami azt illeti, maguk a sötét bőrü helybéliek is inkább tüntek móroknak vagy törököknek, mint keresztényeknek. Ennek ellenére fanatikusan hüek voltak a római egyházhoz" (2015: 151).

Ezúttal nem is eme kortárs irodalmi indító idézet történelmi és világnézeti szemhatárai a fontosak számunkra, hanem annak a látszólagos ellentmondása, hogy egy „mór” nyelvi es antropológiai jellegzetességeket felvonultató, ugyanakkor történelmileg, kulturálisan és felekezetileg egyértelműen Európa felé tájolt szigetlakó populáció nyelvében a keresztény kultuszhoz és hitélethez kapcsolódó szókészlet megőrizte arab jellegét.

Bármely, akár a máltai nyelv általánosságaival, akár annak konkrétabb kérdésfeltevéseivel összefüggésben folytatandó vizsgálódás alapvetése, hogy a máltai kialakulása elválaszthatatlan a sémi nyelvektől. Szükebben szemlélve e genealógiát, elmondható továbbá az is, hogy az arab 
Iványi Márton Pál: Egy látszólagos paradoxon:

a kereszténység fogalmainak arab szókészlete a máltai nyelvben

Argumentum 17 (2021), 878-894

Debreceni Egyetemi Kiadó

DOI: 10.34103/ARGUMENTUM/2021/49

nyelv egy leszármazottjáról van szó, aminek az alapjai vagy a 9., vagy a 11. században alakultak ki, mint majd látni fogjuk, ennek tudományos jelentőségével egyetemben. A máltai felmutatja az északnyugat-afrikai arab egy-egy térségi válfajának jellegzetességeit, habár fejlődési pályafutása hozzávetőleg a tárgyalt időszak óta az arab nyelvi fösodortól gyakorlatilag függetlenül ível (Brincat 2011: xxv, xxxv, 72-73; Borg-Azzopardi Alexander 1997: xiii ; Iványi 2016: 342).

Ebből következően nem meglepő, hogy a máltai szókincs javarésze arab eredetü. Ennek belátásához bőven elegendő ránézni az ország helynévanyagára, ami egyértelműen és vitán felül örzi és tanúsítja a nyelv arab eredetét. Hiszen a baћar ('tenger'; irodalmi arab: $b a h r^{l}$ Wehr 1976: 42; tunéziai arab: marokkói arab: bhar - Harrell 2004: 16), a ghar ('barlang'; IA: $\dot{g} \bar{a} r$-Wehr 1976: 687; TA: $\dot{g} \bar{a} r^{2}$ - Abdelkader 1977: 70 és MA: $\dot{g} a r$ - Harrell 2004: 46), a gżira ('sziget'; IA: ğazīra - Wehr 1976: 123; TA: žazīra - Abdelkader 1977: 204; MA: dzira Harrell 2004: 25), a bir ('kút'; IA: bi'r - Wehr 1976: 39), a Gharb ('nyugat'; IA: garb - Wehr 1976: 668; TA: garb - Abdelkader 1977: 442; MA: gerb - Harrell 2004: 442), a daћla ('beömlőnyílás', 'tengerbemenet'; IA: dahala, yadhulu, 'bemegy' - Wehr 1976: 276), a wied ('völgy' IA: wādin, al-wādī, 'folyó', 'folyóvölgy', 'völgy' - Wehr 1976: 1059; TA: Abdelkader 1977: 329; wād 'folyó' - MA: wad, 'folyó' - Harrell 2004: 203), a több máltai település előtagjaként is szereplő marsa ('kikötő'; IA: marsan, al-marsā 'horgonyzóhely' - Wehr 1976: 340; MA: merșa, 'kikötő' - Harrell 2004: 86), a borg ('halom'; IA: burğg, 'torony' - Wehr 1976: 50; MA: borž, 'torony' - Harrell 2004: 211) szavakban egytöl egyig visszaköszön az arab nyelvi eredet (Brincat 2011: 50; Iványi 2016: 340).

Az ugyanakkor, hogy a máltaiban a kereszténység alapvető fogalom- és szókészlete szintén arab - mint majd e tanulmány, feldolgozva és kiegészítve a vonatkozó szakirodalmat, rámutat -, szerfelett izgalmas kérdésfeltevéseket ösztönöz, további kutatásokat inspiráló nyelvtörténeti problémahalmaz előtt nyitva teret. Főleg arra figyelemmel, hogy egy történeti-társadalmi perspektívában mindig is egyértelmủen a nyugat felé „orientálódó” szigetcsoportról beszélünk.

Messzemenő és részletezett historikus bemutatás helyett ezúttal itt Málta történetének föbb eseményeit pusztán érintőlegesen vázoljuk fel, mindezt a 2.1 fejezetben, a 2.2-es szerkezeti egységben bevezetett ún. nyelvföldrajzi keretek által feltételezett sajátosságok hátterének elnagyolt bemutatására szorítkozva. A lehetséges forgatókönyvek megvitatására a 3. fejezetben véghezvitt szó- és fogalomkészleti empirikus merítést követően a 4. Diszkusszió szakasz tesz kísérletet.

1 Az irodalmi (IA), tunéziai (TA) és marokkói (MA) arab szavak latin abc-s átírásakor a kézirat egésze során a Nemzetközi Szabványügyi Szervezet (ISO) ISO 233 sémáját használjuk, kivéve azon eseteket, amikor a nevezett szabvány nem teszi lehetővé a megfelelö átírást. Ilyenek például a marokkói emfatikus mássalhangzók, melyeket a maguk nem emfatikus megfelelőihez hasonlóan jelölünk. Az ISO 233 nem rendelkezik megfelelő karakterrel a zöngés posztalveoláris affrikáta ( $\breve{g})$ mind a tunéziai, mind a marokkói arab fonetikára időnként jellemzö, zöngés posztalveoláris frikatívaként (ž) történő ejtésének jelölésére, amelyet ugyanakkor indokolt esetben e kézirat során megjelenítünk.

2 Az ISO $233 \dot{g}$ karaktere, amely az irodalmi arabban és a vizsgált nyelvjárásokban a zöngés veláris frikatíva $\dot{g}$ aynra utal, természetesen nem tévesztendő össze a máltai $\dot{g}$-vel, amely a zöngés posztalveoláris affrikátát jelöli. 
Iványi Márton Pál: Egy látszólagos paradoxon:

a kereszténység fogalmainak arab szókészlete a máltai nyelvben

Argumentum 17 (2021), 878-894

Debreceni Egyetemi Kiadó

DOI: 10.34103/ARGUMENTUM/2021/49

\section{Málta és a helyi keresztény lexikon nyelvi fejlődése}

\subsection{A nyelvfejlödés történelmi elözményei}

Alább a máltai szigetcsoport történelmének vázlatos áttekintésével folytatjuk, a fenti problémamegfogalmazáshoz illeszkedve, mintegy „nyelvföldrajzi iránytüként” érintőlegesen a nyelvemlékekre és a szigetcsoport régészeti leleteire is hagyatkozva.

A történelmi idők ködében is szembetünik az, hogy Málta a második pun háború forgatagában római tartomány lett i. e. 218-ban. Az újszövetségi Apostolok cselekedetei (ApCsel 28) kettős tanulsága szerint a romanizáció egyrészt a keresztény hatások már az első évszázadtól érni kezdték a szigetet, amit Szt. Pál apostol partraszállása is jelez. Másrészt az meglehetősen lassan és korlátozottan haladhatott, annak ellenére, hogy egy viszonylag szük és izolált területről van szó, hiszen a fösziget legnagyobb területi kiterjedése mindössze 27 kilométer. A közkeletü feltételezések szerint Málta virágzott a rómaiak alatt. A szigetek szerepelni kezdtek az írásos feljegyzésekben is. A szónok és szenátor Cicero méltatja Melita településen a Junotemplom jelentőségét, valamint egyebek mellett beszámol a szicíliai székhelyủ római kormányzó extravagáns viselkedéséről is. Az itt található villák, templomok és fürdők szilárd és prosperáló élet jeleit mutatják. Az i. e. 1. századból származó Domus Romana 'római ház' néven ismert ház a mai Mdina és Rabat városok közelében nemcsak klasszikus padlómozaikok építészeti-díszítési örökségét vonultatja fel, hanem a korabeli császári dinasztiát ábrázoló márványszobrokat is.

Rabat ezen felül két katakombának ad otthont a római korszak óta, ezek a Szt. Ágota nevét viselő a maga freskóival és Szent Páléi, melyek szintén a római jelenlétről tesznek tanúbizonyságot a kései antikvitás örökségeként. A rómaiak - miként tették egyébiránt például a Balkán esetében is - a kezdeti, például Henryk Sienkiewicz vagy Robert Graves regényeiből is ismert üldözések után türelemmel viseltettek a vallási sokszínűség iránt. Egy további kulcsfontosságú antik helyszín, egy óriási ciszterna található Málta délkeleti részén is, Birżebbuga közelében. Néhány, az ottani római villában kiállított olajlámpa keresztény szimbólumokat jelenít meg, így például Krisztus kezdőbetüit görögül.

A Római Birodalom i. sz. 4. század végi felosztása után a máltai szigetek a Bizánci Birodalom fennhatóság alá kerültek. Ellentétben a talán e helyen szokatlanul terjedelmesen is tárgyalt nyugat-római építészeti örökséggel, ez a kései antik bizánci kor alig-alig hagyott örökül bármit is. A máltai építészet történetével kapcsolatban Leonard Mahoney fogalmazta meg azt a véleményt, hogy „az építészet minden korban a társadalom tükre” (Brincat 2011: 39). Márpedig ennek fényében az építészeti maradványok hiánya gazdasági és társadalmi hanyatlásra, valamint a népesség csökkenésére utal, mindenesetre a szigeten alighanem ekkor már a görög nyelvet beszélték (Brincat 2008: 238). A bizánci időszak további 375 évig tartott, míg az iszlám terjeszkedés jegyében észak-afrikai aglabidák foglalták el a szigeteket i. sz. 870-ben (Brincat 2011; Iványi 2016).

A szóban forgó 870-es fordulathoz lényeges támpontot kínál a korabeli utazó al-Hiimyarī Kitāb ar-raw ̣̣ al-ma 'ṭār fì habr al-'aqțār (kb. 'Könyv az országok hírének illatozó kertjéről') címü beszámolója, amely szerint az erre az évre tett arab inváziót követően a szigetekből nem maradt más, mint „lakatlan rom” (hirbat ġayr āhila). Következőleg annak „öslakossága” elpusztulhatott, tartósan letelepedő népességről pedig nincs szó a 11. század derekáig. AlḤimyarī szerint ugyanis újabb fordulat következik be, amikor 1048 körül muszlim szabadok és 
Iványi Márton Pál: Egy látszólagos paradoxon:

a kereszténység fogalmainak arab szókészlete a máltai nyelvben

Argumentum 17 (2021), 878-894

Debreceni Egyetemi Kiadó

DOI: 10.34103/ARGUMENTUM/2021/49

nagy valószínűség szerint nem muszlim klientúrájuk (az arab szöveg alapján szó szerint $r a b$ szolgáik, irodalmi arabul: 'abìd) érkeztek Máltára, akik együttesen „különb hellyé tették Málta fővárosát, mint amilyen az azelőtt volt” (Brincat 2011: 35-7; Iványi 2016: 343-4).

A lakosság ekképp feltételezett, 870-es kipusztulása értelemszerüen a keresztény rómaibizánci-máltai nyelvi folytonosság ellen szól. Az egyik legizgalmasabb nyelvtörténeti sajátosság a máltaival kapcsolatban is éppen itt jelenik meg, mégpedig a lexikon terén, amelyben különösen árulkodóak és érdekesek a vallási kifejezések.

Bizonyára vannak, akiket meglep, ám tény, hogy Málta több évszázados és mély katolikus hagyománya mellett is, általában a vallási szféra, illetve érdekes módon kifejezetten a keresztény kultusz alapvető elemei zömükben arab eredetüek. Vagyis e tekintetben a római katolicizmus ethosza korántsem eredményezett változást szük ezer év óta a maga erőteljesen latin jellegével együtt sem.

1091-ben I. Roger vezetésével a szicíliai normann erök vették birtokba a szigeteket, amelyeket akkoriban - vagy túlnyomórészt, vagy kizárólag - muszlimok lakhattak. Joseph M. Brincat (2011: 58) máltai nyelvész szerint a keresztények első kifejezett említése 1090-ből való, és a történész Godfrey Wettinger (1995: 38-9) szerint sincs érdemi bizonyíték arra, hogy az 1091es betörés idején a máltai szigeteken fennmaradt volna túlélő „öshonos” keresztény lakosság. Roger király 1127-es inváziója volt az, amely állandó politikai változást hozott a szigeteken, megteremtve egy keresztény berendezkedés létrehozásának feltételeit. Kezdetét vehette az állandó népesebb keresztény letelepedés, föként a helyőrség, a közigazgatási és egyházi szereplők, valamint a kereskedők részvételével. Létszámuk mindenesetre nem lehetett különösebben nagy, máskülönben nyelvük felváltotta volna az arab nyelvjárást, amely utóbbi végül máltai nyelvvé fejlődött. Az iszlám 1127 után sokáig uralkodó volt a szigetlakók körében, és egészen 1250-ig fennmaradt.

Ami pedig az északnyugat-afrikai politikai és nyelvi színteret illeti: még azelött, hogy a kereszténység visszahódította volna Máltát, a Magreb térséget az Arab-félszigetröl érkezett Banū Sulaym és Banū Hilāl törzsek vették birtokukba. Ennek eredményeként Északnyugat-Afrikát az arabizáció második hulláma is elérte a maga beduin nyelvjárási típusainak a hatásaival, amely azonban Máltára már nem volt befolyással. Ez hozzájárulhatott ahhoz a tényhez, hogy a máltai nyelv bizonyos szempontokból és fokig archaikusabbnak tekintendő, mint egyes magrebi nyelvjárások (Kontzi 1986: 24).

\subsection{Nyelvföldrajz és a szókészlet rétegzödése}

Egy tetszőleges nyelv szókészleti rétegződése egy sor módon szemlélhető, ekképp az úgynevezett nyelvföldrajzi paradigma perspektívájából is. A geolingvisztika bebizonyította, hogy a nyelvek nem csak függőleges, genealógiai vonal mentén fejlődnek (az idő változásával), hanem vízszintes síkon is, szomszédos nyelvek és nyelvjárások által. Végül is az egyének közösségben élnek, és ennek következtében a közösségen belüli és a különböző közösségek tagjai közötti társadalmi és kereskedelmi eszmecserék nyelvi hatásokkal járnak. A régóta fennálló kapcsolatok tehát rétegtani (sztratigráfiai) mintázatként is megjeleníthetök, ahol a különböző szintek (rétegek, latinul: stratum, tsz.: strata) meghatározott történelmi időszakokra vonatkoznak. E máskülönben - a vízrajzi modellel ellentétben, ahol az egyes nyelvek kölcsönhatásai inkább a tavak és folyók áramlási dinamikáira emlékeztetnek -, némileg statikusnak (Brincat: 2011: xxix; Iványi 2016: 343) is tekinthető elrendezés segítséget nyújt egy-egy szókészlet hozzávetőleges elhelyezéséhez a történelmi időszakok tekintetében 
Iványi Márton Pál: Egy látszólagos paradoxon:

a kereszténység fogalmainak arab szókészlete a máltai nyelvben

Argumentum 17 (2021), 878-894

Debreceni Egyetemi Kiadó

DOI: $10.34103 / A R G U M E N T U M / 2021 / 49$

A szubsztrátum vagy a nyelv alaprétege különböző jellegzetességekből (szavakból, hangokból, formákból és a köznyelvi kifejezések tükörfordításából) tevődik össze, amelyek akkor is fennmaradnak, ha egy közösség történetesen elhagyja a nyelvet, és újat vesz fel. Különbözö tényezők okozhatnak efféle közösségi nyelvcserét. A leggyakoribb ilyen események a katonai hódítások és a gyarmatosítás, amelyek a régi mellett új nyelvet is bevezethetnek (pl. ír-angol nexus), a politikai hatalom támogatásával szorítva ki előbbit utóbbi által, vagy egyszerűen azért, mert a telepesek létszáma népesebb, mint az eredeti lakosságé. Ez utóbbiak ezáltal arra kényszerülnek vagy ösztönöztetnek, hogy szokásukban és beszédükben alkalmazkodjanak az új helyzethez.

Egy terület nyelvtörténete ugyanolyan bonyolult, mint egy adott lakosság politikai története. Mondhatni, néha már egyenesen célszerübb, kényelmesebb is nép helyett területről beszélni, mert egy terület lakóinak etnikai összetétele változhat, alkalmasint drasztikus mértékben is.

A rétegtani minta jelentősége és hasznossága egyebek mellett abban is rejlik, hogy tudatosítja bennünk a változások tényét. A kiindulópontot mindig a fó réteg képezi, amely általában a legerősebb és felmutatja a genealógiai származási vonalat. Ezt az alapvető szókincs határozza meg, amely a leggyakrabban használt szavakból áll, miközben ezek gyakran kisebbségben vannak az egyéb szavakhoz képest. Determinálja azt a morfoszintaxis, amely lassabban változik, mint a szókincs. Az alapréteg (substratum) azt örzi, ami fennmaradt az egykori nyelvböl, míg a fö réteg fölötti szint felső réteg (superstratum) néven ismert, és azt mutatja, hogy egy adott időszakban erős kapcsolat alakult ki egy másik nyelvvel. Ez utóbbi nem váltotta fel azt, amelyet fö rétegnek neveztünk, mert a kapcsolat egy bizonyos időpontban megszakadt és soha nem folytatódott (Brincat 2011: xxvi-xxviii).

Amint arra Brincat (2011: xxxv) rámutat, a máltai nyelv esetében beszélhetünk egy i. e. 650 50 közötti pun, egy i. e 218-i. u. 476 közötti latin és 535-870 közötti bizánci (görög) alsó rétegről, egy (870?)-1048-1241 (szicíliai?) arab fö rétegröl, egy (1090)-1148-kb. 1900-ig tartó szicíliai felső rétegről és a kora újkori, illetve kései modern korral kezdődően ezekkel együttható olasz és angol rétegekről (adstrata).

\section{Az arab fogalom- és szókészlet}

Nemcsak egy-egy nyelv tematikus szókészletének alapjait, hanem annak esetleges változásait is kitapintandó kézenfekvő a széles közösségi ismertségen nyugvó nyelvemlékekhez fordulni, aminek egyébként érthetően hosszú hagyományai is vannak. Ennek belátásához elég, ha a magyar nyelv vonatkozásában az Ómagyar Mária siralom jelentőségére és emlékezetére gondolunk, amely bőven szolgáltat elgondolkodtató tanulságokat nyelvtörténetünk középkori szakaszait illetően.

Ebben a szellemben alább a máltai Missierna ('Miatyánk') és a Kredu ('Apostoli hitvallás') keresztény imádságok szövegeit vizsgáljuk meg tüzetesebben, ekképp egyszerre kísérelve meg kimutatni az arab nyelvi eredet tényét és a vonatkozó szókészlet viszonylagos módosulásait az idők folyamán a muszlim/keresztény váltást is figyelembe véve.

Missierna, li Inti fis-smewwiet, jitqaddes ismek, tigi is-saltna tieghek, ikun li trid int, kif fissema hekkda fl-art. Hobżna ta' kull jum, agћtina llum. Aћfrilna dnubietna bћalma naћfru lil min hu hati ghalina. La ddahalniex fit-tigrib, iżda eћlisna minn kull deni. Hekk ikun. 
Iványi Márton Pál: Egy látszólagos paradoxon:

a kereszténység fogalmainak arab szókészlete a máltai nyelvben

Argumentum 17 (2021), 878-894

Debreceni Egyetemi Kiadó

DOI: 10.34103/ARGUMENTUM/2021/49

Érdekes módon a Missierna (Miatyánk) szövegének mindössze egyetlen szava indoeurópai eredetű: Missier 'Atya'. Ez a 'felvigyázó' jelentésủ szicíliai misseri szóból származik , a maga morfológiai módosulásaival. Hiszen, még a Missierna, e máskülönben indoeurópai határozott tulajdonnév - ami egyébiránt a bu ('apa' IA: $a b(\bar{u})$ - Wehr 1976: 2; TA: bū - Abdelkader 1977 : 469; MA: bu - Harrell 2004: 13) helyébe lépett a máltaiban, sem független alaktanilag a sémi hatásoktól, amint azt az 'imāla -amely egy nyílt magánhangzóba hajló kiejtés referenciája, amit a máltaiban mindig a hangsúlyos hosszú magánhangzó ${ }^{4}$ ie jelenti -, és az utótag -na birtokos személyjel egyaránt mutatja.

Az alábbiakban csakis a Missierna egyéb, vallásos világnézethez és hithez kifejezetten kapcsolódó szavait tekintenénk át e tanulmány problémamegfogalmazásával összefüggésben:

fis-smewwiet ('mennyekben', IA: fî's-samawāt/samāwät, 'menny', 'ég' - Wehr 1976: 432; TA: smāwāt, 'egek' - Abdelkader 1976: 361; MA: smawat - Harrell 2004: 138);

jitqaddes ('szenteltessék meg' IA: yataqaddusu, 'megszenteltetni' - Wehr 1976: 747; Aquilina 1972: 72; Aquilina 2006: 294; Agius 2005); Ennek az V. igetörzs ${ }^{5}$ folyamatos alakban álló igének a gyökmássalhangzói az arab rokonnyelveken egy sor egyéb szóban köszönnek vissza: pl. qaddis ('szent' (fönév és melléknév) IA: qiddīs - ; Ghid il-Qaddisin Kollha ('Mindenszentek', IA: 'İd kull al-qiddīsinn); Quddiesa (tsz.: Qdiedes, 'mise' IA: quddās, qadād̄̄ss); Qdejdsa és Qdejsa ('kismise'); quddiesa tel-mewt ('gyászmise', szó szerint: a 'halál miséje' - Wehr 1976: 930; IA: mawt, TA: mūt - Abdelkader 1977: 505; MA: mut - Harrel 2004: 92). Qaddies (tsz.: qaddiesin, 'szentmisét tartó pap'); qaddes ('szentté avatni', 'szentmisét tartani' IA: qaddasa; MA: qeddes - Harrell 2004: 112); taqdis ('meg- vagy felszentelés'; IA: taqdīs) ${ }^{6}$; Ruћ il-Qodos ('Szentlélek' IA: (ar-)Rūh (al-)-qudus); Ktieb Mqaddes ('Szentírás', 'Biblia' IA: (al-)kitāb (al-)muqaddas; itt a hátravetett jelzős szerkezet egyik tagja a 'szent' melléknév IA: muqaddas; TA: muqaddis - Abdelkader 1977: 335; MA: mqeddes - Harrell 2004: 100);

Továbbmenve: Ahfrilna 'bocsásd meg [nekünk]' IA: ġafara - Wehr 1976: 677-7; MA: ġfer Harrell 2004: 47);

3 Mely szicíliai szónak egyébként a távoli rokona lehet a francia monsieur is.

4 Meglátásom szerint, ellentétben pace Trimble 1973 nézetével, az ie a máltaiban nem diftongus, hanem hosszú magánhangzó inkább.

5 A szövegben szereplő római számos elrendezéshez csakúgy, mint a párhuzamosan használt igetörzs fogalmához a következő háttérismeret indokolt: Az arab nyelv egyik legfőbb szóképzési módját az igetörzsek használata jelenti, hasonlóan a többi sémi nyelvhez. Ezek lényegében olyan meghatározott sablonok, amelyekben az alapjelentést hordozó gyökökhöz járuló pre- és infixumok, valamint az írásban csak mellékjelekkel jelölt magánhangzók azonosak úgy az igealakok, mint az igenevek és a névszói értelmü maszdar (ar.: mașdar) esetében. Nem összetévesztendő a nemet, számot, állapotot, módot stb. kifejező igeragozással: ennek funkcióját nem az igetörzsek töltik be, hanem az összes igetörzsben azonos igeragok. Bár az egyes igetörzsek - például a magyar képzőkhöz hasonlóan - meghatározott jelentéstartalmat hordoznak (pl. müveltetés, visszahatás, kölcsönösség stb.), ez nem minden esetben egyértelmü és megfogható.

6 A 'felszentelés' vitathatóan absztraktabb fogalmával, noha elterjedtebb olasz átvétellel a máltaiban a konsagrazzjoni (Aquilina 2006: 205), azért találkozni sémi alakban is, például az ismételten prepozíciós szerkezettel kifejezett Taqdis tal-Knisja ('templom felszentelési fesztiválja') birtokviszonyban. 
Iványi Márton Pál: Egy látszólagos paradoxon:

a kereszténység fogalmainak arab szókészlete a máltai nyelvben

Argumentum 17 (2021), 878-894

Debreceni Egyetemi Kiadó

DOI: 10.34103/ARGUMENTUM/2021/49

dnubietna 'büneinket' (esz.: Dnub; 'büneinket' IA: danb, dunū $b^{7}$ - Wehr 1976: 312; MA: denb, dnub - Harrell 2004: 22). Itt jegyezném meg Agius (2005) nyomán, hogy e szóval más összetételekben is találkozni az imák kontextusán kívül is: dnub tan-nisel 'eredendő bün' IA: nasl Wehr 1976: 962);

tigrrib ('kísértés' IA: tağrīb - Wehr 1976: 118);

deni ('gonosz' IA: danī'/danīy, 'aljas', 'megvetendő - Wehr 294-295);

eћlisna ('szabadíts meg [minket] IA: h̆alașa, yah̆lușu 'felszabadul', 'megtisztul', 'üdvözül' Wehr 1976: 254; MA: helleș (menn) 'megszabadul (vmitöl)';

A sémi szavak túlsúlya mellett a sémi szintaktikai és morfológiai alakzatok ugyanolyan magas arányát látjuk itt. Trimble (1973: 61) szerint az egyetlen nem sémi eredetü ${ }^{9}$ szintaktikai konstrukció a szövegben azon többszörösen összetett birtokviszony, amelyet a körülírt (perifrasztikus) ta' prepozíciónak egy fönév-főnév status constructus szerkezettel együtt történő használata fejez ki:, Hobżna ta' kull jum 'mindennapi kenyerünket'.

Az ima jelenlegi máltai változatának prepozíciós vagy más néven körülírt (perifrasztikus) alakzatai Trimble szerint valószínüleg a modern máltai nyelv azon erős tendenciájának és indíttatásának az eredményei, hogy prepozícióval helyettesítse az irodalmi arab status constructus mintáit. Azonban, amint azt az alábbiakban megjegyezzük, a máltai vallási kifejezésekben a perifrasziszra való áttérés lassan történik. Valójában a bizonyítékok azt a preferenciát mutatják, hogy abban az esetben, ha a hagyományos kifejezések teljes egészében sémi szavakból tevődnek össze, akkor általában hosszabb ideig maradnak a "hagyományos" konstrukcióban (Trimble 1973: 60-61).

Nincs is talán szükség a Miatyánk egyéb - máskülönben szintén sémi eredetü - szavainak tárgyalásához annak észrevételéhez, hogy a keresztény kultusz szókincsét mintegy sémi keresztségben nyeri el a máltai nyelv.

Ezt támasztja alá az Apostoli hitvallás máltai nyelvü verziója (Il-Kredu ta' l-Appostli, a továbbiakban: Kredu) is az alábbiak szerint:

Jena nemmen f' AlIa I-Missier, li jista' kolIox, li halaq is-sema u I-art u f'Ǵesù Kristu ibnu wiehed Sidna, li kien konċeput mill-Ispirtu s-Santu, twieled minn Marija Verġni, bata taht ilI'haqq ta' Ponzu Pilatu, kien mislub, miet, u difnuh. Niżel fil-Limbu, u fit-tielet jum qam minn bejn l-imwiet. Tala' fis-smewwiet, u qieghed in-naha tal-Iemin t' Alla I-Missier, li jista' kollox. Minn hemm ghandu jigi jaghmel haqq mill-ћajjin u mill-mejtin. Nemmen fl-Ispirtu s-Santu, ilKnisja mqaddsa Kattolika xirket il-Qaddisin, il-maћfra tad-dnubiet, il-qawma ta' 1-imwiet, ilhajja ta' dejjem. Ammen.

\footnotetext{
Alapige az 'a $\underline{d}$ naba IV. igetörzs

8 Érdekességképp: ehhez a II. igetörzsbeli igéhez a jelenkori magrebi (MA, TA) nyelvjárásokban már elsősorban a fizet jelentés kapcsolódik (vö.: Harrell 2004: 140)

9 Trimble itt nyilvánvalóan kizárólag az irodalmi arabot veheti alapul, nem pedig a modern dialektusokat. Hiszen ellentétben előbbi sajátosságaival, a körülírás szóban forgó szintaktikai mintáját gyakorlatilag az összes arab nyelvjárás jól ismeri Marokkótól Irakig és azon túl. E distinkcióval, illetve az irodalmi arab konkretizálással a diglosszia fényében értjük, mire gondolhatott abban ugyanakkor, hogy ez egyértelmúen ne sémi szabvány lenne, téved pace Trimble 1973 a nyelvjárások eme említett preferenciája tükrében. Abban azonban irodalmi arab verzió összehasonlításképp: hubzanā kafäfanā 'a 'tinā.
} 
Iványi Márton Pál: Egy látszólagos paradoxon:

a kereszténység fogalmainak arab szókészlete a máltai nyelvben

Argumentum 17 (2021), 878-894

Debreceni Egyetemi Kiadó

DOI: $10.34103 / A R G U M E N T U M / 2021 / 49$

A Kredu a Kr. u. 4. század végére érte el jelenlegi formáját. Így feltételezhetjük, hogy az ima jóval az arab hódítás előtt elérte Máltát, és ezért ugyanolyan hatásoknak volt kitéve, mint a Missiema. Mégis, az elemzés tükrében a Kreduban több mint háromszor akkora a nem-sémi szavak aránya, mint a Missiemában. Mindez bizonyítékokat szolgáltat a vallási kifejezések első három (arab előtti, arab és a poszt-arab) időszakának rétegére is (Trimble 1973: 61-63).

nemmen ('hisz', IA: āmana, yu'minu 'hisz' - Wehr 1976: 28; TA: ammna 'hisz' pl. mā nammnikš 'nem hiszek neked' - Abdelkader 442; MA: 'amen, 'hisz', 'bízik' - Harrell 2004: 2);

Alla ('Isten', IA és TA: 'Allāh - Wehr 1976: 24; MA: llah - Harrell 2004: 71);

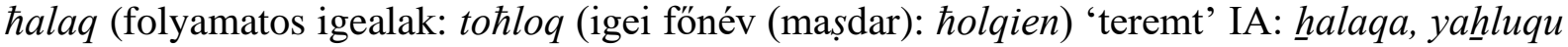
- Wehr 1976: 258; TA: ahlaq mașdar: hllaq - Abdelkader 1977: 95; MA: hlleq mașdar: hliq Harrell 2004: 216);

mislub ('megfeszített' IA: maṣlūb Wehr 1976: 521). Itt érdemes ismét egy kitérőt tenni az azonos gyökmássalhangzókból képzett egyéb rokonszavak felé, miként tettük azt a qadusa derivált szavai esetében is fentebb: salib (tsz.: slaleb 'kereszt' IA: șalīb (tsz.: șulbān, șulub, Wehr 1976: 521; MA: șalib - Harrell 2004: 143); sallab ('keresztre feszít' IA: șallaba és mașdarja, a tisliba - Aquilina 2006: 327); Radd is-salib ('keresztet vetni'); Xahar is-Salib ('a Szent Kereszt felmagasztalásának, vagy Szent Mihálynak a hónapja (szeptember; IA: šahr 'hónap' - Wehr 1976: 491; TA: šhar - Abdelkader 1977: 248; MA: šher - Harrell 2004 II: 126); földrajzi helynevek: Misrah is-Salib, Tal-Mislub, Hagar is-Salib;

il-Knisja mqaddsa ('Anyaszentegyház' IA: (al-)kanīsat al-muqaddasa; knisja ('templom' IA: kanīsa - Wehr 1976: 842; TA: knīsiyya Abdelkader 1977: 77; MA: knisiya - Harrell 2004: 64; (Aquilina 1972: 71)); Újabb exkurzus következik: knejsa (tsz.: knejjes); 'kápolna', amely a következő három, máltai szigeten fekvő földrajzi helynévben is szerepel: Ras il-Knejjes , Wied il-Knejjes , Tal-Knejjes (Agius 2005).

Xirket il-Qaddisin ('a szentek közössége' IA: širka, šarika 'közösség', 'társulás' - Wehr 1976: 468-9; A: šarīka - Abdelkader 1977: 84; MA: šarika - Harrell 2004: 151);

il-maћfra tad-dnubiet ('a bünök bocsánatát' - fentebb érintettük a kapcsolódó szavakat, itt az előbbi maṣdar alakban jelentkezik, a. m. 'megbocsátás' IA: maḡfira - Wehr 1976: 677);

il-qawma ta' l-imwiet ('a test [szó szerint holtak] feltámadását' IA: qawma 'felkelés', 'emelkedés' - Wehr 1976: 800 és 'holtak', IA: amwāt - Wehr 1976: 930; TA: mūta; Abdelkader 1977: 100; MA: muta - Harrell 2004: 80).

Akárcsak az Il-Missiema esetében, az Il-Kredu is lexikailag és szintaktikailag alapvetően sémi, bár hat főnévi-fönévi birtokos szerkezetéböl csak egy esetben maradt fenn a „hagyományos” (a.m. IA-szabványt követö) status constructus állapotban, ez a már fentebb beharangozott Xirket il-Qaddisin 'Szentek közössége'. A modern angol-máltai szótára jelenlegi formájában a körülírt (a.m. prepozícióval kifejezett) ix-Xirka tal-Qaddisin alakzatot adja meg, jelezve ezzel, hogy az imában szereplő kifejezés e fenti formájában egy régebbi, archaikus alak. Eme „elavult” jellegére vonatkozó további bizonyítékot a nőnemet jelző Tă marbūṭ megtartása 
Iványi Márton Pál: Egy látszólagos paradoxon:

a kereszténység fogalmainak arab szókészlete a máltai nyelvben

Argumentum 17 (2021), 878-894

Debreceni Egyetemi Kiadó

DOI: $10.34103 / A R G U M E N T U M / 2021 / 49$

szolgáltat, ami a modern máltaiban már szintén anakronizmus és immár pusztán egyes hasonló, „túlélt” nyelvemlékekben találkozni vele (Trimble 1973: 60-61).

Ami a máltai nyelv további, nem sémi vagy „hibrid” rétegeit illeti, ebben az imában nyolc olyan kifejezést találunk, amelyeknek etimológiai eredete indoeurópai: (1) Gesu Kristu ('Jézus Krisztus' olasz: Gesù Cristo); (2) Marija Vergni ('Szüzmária' ol.: Maria Vergine); (3) Ponzu Pilatu ('Poncius Pilátus', ol.: Ponzio Pilato); (4) Kattolika ('katolikus' ol.: cattolica); (5) Missier (a szövegben kétszer, már tárgyaltuk fentebb); (6) I-Ispirtu s-Santu ('Szentélek' ol.: Spirito Santo); (7) Limbu ('pokol', 'pokol tornáca', ol.: Limbo) és (8) koncieput ('fogantatott' ol.: concepito). Ezek közül az első három, a hatodik és a hetedik keresztény kifejezés, amelyek akár már az arab időszak előtt (emlékeztetőül, 870 előtt) is bekerülhettek a nyelvbe, jóllehet jelenlegi formájuk fonetikus módosítása csakis az arab uralom idején vagy azt követően következhetett be. A fennmaradó három kifejezés - Kattolika, Missier és konćeput nyilvánvalóan a szicíliai normannok érkezése után, illetve a római katolicizmus berendezkedés kezdetével keletkezett máltai szavak.

Természetesen az arab eredetü lexémák köre korántsem szükül le e két jelentőségteljes imára. Se szeri, se száma az idetartozó szavaknak és kifejezéseknek, a fentebb felsoroltakon kívül, távolról sem a teljesség igényével, következzen egyebek mellett néhány, különböző kategóriákba rendezve:

Általános metafizikai fogalmak:

ġnien ('mennyország', IA: ğanna - Wehr 1976: 138; TA: žanna - Abdelkader 1977: 278; MA: ženna - Harrell 2004: 235);

Gћodda t'Alla (ez a kifejezés szó szerint 'Isten eszközeit' jelenti, valamikor a szentségek, különösen az utolsó kenet összefüggésében használták, amelyről úgy tartják, hogy gyógyító hatása is van, ha haldoklónak adják, IA: 'udda - Wehr 1976: 594-5; Aquilina 1972: 73; Aquilina 2006: 151).

Mulej ('Uram' - IA: mawlāya 'Uram', „uralkodóm' (elsődlegesen szekuláris értelemben!) Wehr 1976: 1101; TA: mūla 'tulajdonos' - Abdelkader 1977: 275; MA: mula 'tulajdonos' Harrell 2004: 21; Aquilina 2006: 247);

ide sorolnám még a vizsgált szakirodalmi tételek szószedeteinek egyikében sem szereplő: xitan 'sátán', 'démon' - Aquilina 2006: 403; TA: šițān - Abdelkader 1977: 108; šiṭan - Harrell 2004 II: 50).

\section{A legfontosabb ünnepek:}

il-Milied ('karácsony', IA: ‘ìd al-mīlād - Wehr 1976: 1098; TA: ‘ìd mīlād (sayyidna 'īsa) Abdelkader 1977: 77; MA: milad l-masih-Harrell 2004: 80; Aquilina 1972: 71);

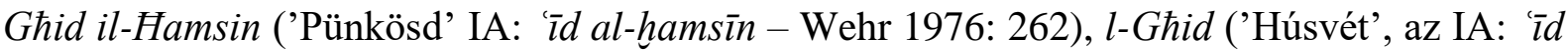
- Wehr 1976: 661; TA: MA: ‘id 'ünnep' köznévből jelentésátvitellel érlelödött tulajdonévvé); és a később részletesebben tárgyalt ir-Randán ('nagyböjt', IA: ar-Ramaḍān-Wehr 1976: 360 TA: rum

Hamis il-Kbir ('Nagycsütörtök' IA: hamamis 'csütörtök' - Wehr 1976: 262; TA: h̆mīs Abdelkader 1977: 411; MA: hmis - Harrell 2004: 217; és IA: kabìr 'nagy' - Wehr 1976: 810; TA: kbirr - Abdelkader 1977: 492; MA: kbir - Harrell 2004: 61; Aquilina 1972: 73); 
Iványi Márton Pál: Egy látszólagos paradoxon:

a kereszténység fogalmainak arab szókészlete a máltai nyelvben

Argumentum 17 (2021), 878-894

Debreceni Egyetemi Kiadó

DOI: $10.34103 / A R G U M E N T U M / 2021 / 49$

il-Ghid il-Kbir ('Húsvét', szó szerint 'a nagy ünnep' - Aquilina 1972: 72);

il-Gimgha l-Kbira ('Nagypéntek' IA: ğum 'a 'péntek' - Wehr 1976: 135; TA: žum 'a Abdelkader 1977: 508; MA: žumu 'a, žem 'a - Harrell 2004: 235; 236; Aquilina 1972: 73 Aquilina 2006: 157);

Ghid iż-Żebbug ('a böjt hatodik, Virágvasárnapja', szó szerint: 'az olajág ünnepe' (Aquilina 1972: 73), amelyben a máltai żebbug szó arab előzménye valójában berber kölcsönzés - Dozy (1881: 605) -, ami máskülönben szintén az északnyugat-afrikai arab nyelvjárások felé tolja a máltai eredetét.

Sibt il-Ghid ( Nagyszombat' IA: as-sabt 'szombat' - Wehr 1976: 393; Aquilina 1972: 73 TA: (nhār is)sibt - Abdelkader 1977: 508; MA: sebt - Harrell 2004: 134)

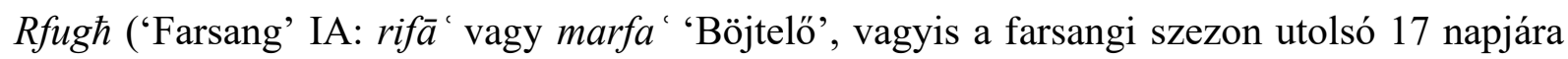
kiterjedő időszak - Wehr 1976: 350; Agius 2005);

Hadd il-Gid ('Fehérvasárnap', illetve a magyar néphagyományban átkáló vagy komáló vasárnap - Aquilina 1972: 71).

Újabb kategóriát képeznek az eddigieken felül a keresztény intézményi rendszer elemei:

nisrani ('keresztény', IA: nașrān̄i-Wehr 1976: 970; MA: nesrani-Harrel 2004: 104; Aquilina 2006: 256);

qassis ('pap', IA: qissīs - Wehr 1976: 762; Aquilina 1972: 72; Aquilina 2006: 299), amely előfordul a következő máltai földrajzi helynevekben is: Ta Qassisu, ix-Xagћra tal-Fuqanija talQassis;

Raћeb ('szerzetes', remete' IA: rāhib - Wehr 1976: 362; MA: rhib - Harrell 2004: 126; Aquilina 2006: 306), amelyet a következő toponímiák is őriznek: Ras ir-Raћeb, Wied irRaaћeb, Ta Rћieb, Tar-Raheb.

Érdekes eset, egyben a (bizánci) görög epískopos szó közvetlen, vagy közvetett megöröklésének lehetőségét is felveti az isqof (tsz.: isqfijiet 'püspök' IA: 'usquf, asāqifa Wehr 1976: 17; Aquilina 1972: 71; Aquilina 2006: 179); visszaköszön a szó máltai földrajzi helynevekben is: Wied l-Isqof, ix-Xaghra ta' l-Isqof (Agius 2005)

Isqfija ('püspöki székhely', 'püspökség' (pl. székhely) IA: usqufìya - Wehr 1976: 17; Aquilina 2006: 179)

Arab eredetüek egyes hitgyakorlás vonatkozású, vagy liturgikus elemek is:

talb ('ima' IA: țalb - Wehr 1976: 563; TA: țalab - Abdelkader 1977: 104; MA: talab, 'kérés' - Harrel 2004: II. 48; Aquilina 2006: 364);

tqarbin ('eucharisztia' IA: qurbān - Wehr 1976: 755) és rokonszavai, pl. qarben ('Eucharisztiát, úrvacsorát adni'); tqarben ('úrvacsorát vesz' (szenvedö alak); tqarbin ('úrvacsora szentsége'); qorban ('szentostya', illetve engesztelö áldozat - Aquilina 1972: 72; Agius 2005; Aquilina 2006: 298); 
Iványi Márton Pál: Egy látszólagos paradoxon:

a kereszténység fogalmainak arab szókészlete a máltai nyelvben

Argumentum 17 (2021), 878-894

Debreceni Egyetemi Kiadó

DOI: $10.34103 / A R G U M E N T U M / 2021 / 49$

qrar ('gyónás', IA: 'aqrara IV 'bevall', 'elismer' - Wehr 1976: 751-3; MA: gerr - Harrell 2004: 44; Aquilina 1972: 73; Aquilina 2006: 298); és a rokonszavak: qarr, iqerr, Tqarar VI és Stqarr X ('gyón', igei föneve vagyis mașdarja (Aquilina 2006: 298); amelyek közül a legutóbbi befejezett cselekvő melléknévi igeneve a következő közmondásból is visszaköszön: Id-dnub ilmistqarr nofsu maћfur 'a meggyónt bün az félig meg van bocsájtva' - Agius 2005);

daqq tal-mewt ('lélekharang', máltai daqq, ydoqq 'harangozni', 'zenélni' IA: daqq, yaduqqu 'üt, zúz' - Wehr 1976: 287; TA: daqq, yduqq - Abdelkader 1977: 211; MA: degg, idogg Harrell 2004: 20) és daqq tal-qanpiena harangzúgás, ahol az előtag, vagyis a birtok arab eredetü;

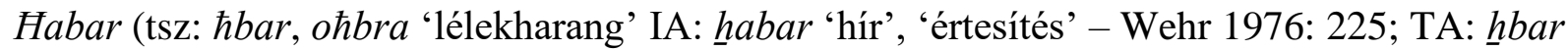
- Abdelkader 1977: 256; MA: hbar - Harrell 2004: 213; Aquilina 2006: 153;

deffien 'sírásó' (IA: dafana 'ás' - Wehr 1976: 287; TA: idfin - Abdelkader 1977: 59; MA: dfen - Harrell 2004: 20

ilma mbierek ('szentelt víz' IA: al-mā' 'víz' - Wehr 1976: 932; TA: $m \bar{a}$ - Abdelkader 1977: 496 MA: ma Harrell 2004: 75) és 'szent' IA: mubārak 'áldott' - Wehr 1976: 54; MA: mbarek - Harrell 2004: 5);

l-ghasar 'vecsernye' (IA: 'așr Wehr 616 'idő', 'délután', '(muszlim) délutáni ima' MA: 1- 'aser Harrell 2004: 254; Aquilina 1972: 73; Aquilina 2006: 148);

magћmudija keresztelés (IA: ma 'mūdiya 'keresztelés', amely az első a római katolicizmus hét szentsége közül - Wehr 1976: 643; Aquilina 1972: 71;Aquilina 2006: 146).

Egy további szócsoport az emberi és társadalmi élethez kapcsolódó egyéb olyan fogalmak, amelyeknek vallási rituális összefüggéseik (is) lehetnek, igaz, nem kizárólagosan vagy nem feltétlenül a kereszténységgel kapcsolatban, így:

Din (tsz.: djien ('vallás' IA, TA és MA: dīn, adyān - Wehr 1976: 306; Abdelkader 1977: 320; Harrell 2004: 21; Aquilina 2006: 82);

Tewba ('bünbocsánat' IA: tawb(a) - Wehr 1976: 98-9; Aquilina 1972: 72; Aquilina 2006: 373);

Xbin (tsz.: xbejjen 'keresztszülő’ IA: šabīn, šabāyin - Wehr 1976: 453; Aquilina 2006: 399);



zwieg (tsz.: zwiegijiiet 'házasság, esküvő' Aquilina 1972: 72 (IA: zawā̆g vagy zīğa Wehr 385; TA: zūz 'pár' - Abdelkader 1977: 534; MA: zwaž - Harrell 2004: 230 );

gћors ('házasság' - Aquilina 2006: 148; IA: 'urs - Wehr 1976: 602; TA: 'irs Abdelkader 1977: 231; MA: 'ris 'vőlegény' - Harrell 2004: 262) és a kapcsolódó máltai, V. igetörzsbeli tgћarras ('házasodni');

gilwa (egy ősi máltai népszokás, amely során a menyasszony és a vőlegény a nekik dicshimnuszokat éneklö, élő zenét játszó énekesek kíséretében érkezik a templomba, IA: ǧilwa 'a menyasszony leleplezése' - Wehr 1976 32; Aquilina 2006: 130); 
Iványi Márton Pál: Egy látszólagos paradoxon:

a kereszténység fogalmainak arab szókészlete a máltai nyelvben

Argumentum 17 (2021), 878-894

Debreceni Egyetemi Kiadó

DOI: $10.34103 / A R G U M E N T U M / 2021 / 49$

qabar ('koporsó' IA: qabr - Wehr 1976: 738; TA: qbar Abdelkader 1977: 174; MA: qbur 'sír' Harrell 2004: 111; vö. Aquilina 1971: 28; Brincat 2011: 56; Iványi 2016: 352).

Újabb kategória a templomi kellékeké:

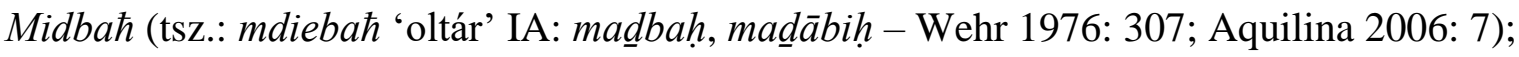

bahћar ('füstöl' például Húsvétkor a szemmelverés ellen (ang: censer, thurible) Bhur ('tömjén', bah̆ūr, mibhhara 'füstölö' - Wehr 1976: 43; Aquilina 2006: 45);

ide sorolható még a sémi és/vagy görög eredetü lubien ('tömjén' IA: ‘(fenyő)tömjén' IA: Wehr 1976: 856; koiné görög: líbanos);

Dejr ('kolostor', 'monostor' IA: dair - Wehr 1976: 300), amely a következő földrajzi helynevekben szerepel: Abbatija tad-Dejr, Dejr il-Bniet.

\section{Diszkusszió}

Az egyéb nyelvészeti aspektusokból is roppant izgalmas máltai nyelvvel kapcsolatban a legérdekesebb probléma a keresztény szókészlethez, és a lakosság folytonosságához kapcsolódik.

A máltai nyelvtörténet érdekfeszítő tanulságokat kínál a bizánci és egyéb hatások viszonylagos érvénye összefüggésében. Teszi ezt két perspektívából is: egyfelől a 870-es arab hódítást (Brincat 2011; Iványi 2016) megelőző időszakból gyakorlatilag nem maradtak latin-görög nyelvi elemek még azon keresztény vallási kultuszhoz kapcsolódóan sem, aminek a jelenléte máskülönben jól dokumentált a szigetcsoporton. Ez elörevetíti, hogy a Bizánc fémjelezte időszak vége vízválasztó Málta tekintetében. Másfelöl, a szigetcsoporton beszélt nyelv keresztény fogalomkörhöz kapcsolódó szavai arabul kezdik betölteni ezt az ürt e fordulat után, mely nyelvi aljréteget (lat.: substratum) a későbbi olasz neolatinizációs hatások sem fogják tudni kiszorítani. Természetesen nem egy olvasat létezik. Joseph Aquilina (1972: 74) nyelvész szerint például akár az sem elképzelhetetlen, hogy az arab szavak beépülése a nyelvbe nem a 9. században, hanem jóval korábban, már a kései antikvitás idején ment volna végbe levantei maronita keresztények által, ám e nézet igen kevéssé nyert tudományos támogatottságot.

Ugyanakkor a máltai színtér párhuzamos társadalmi és kulturális, illetve nyelvhasználati kereteivel kapcsolatban érdekes, izgalmas analógiát és ellentéteket mutat a közel-keleti maronita keresztények szír-arámi vagy ciprusi arab nyelvének, emellett a judeo-arabnak a fennmaradása is, amelyek egyszersmind a jövő kutatási szempontjainak, irányainak is tájolói lehetnek. ${ }^{10}$

10 Ezek érintőleges bemutatása előtt az arab (nyelvü) keresztényekkel kapcsolatban egy, a jelen tudományos élethez és intézményi világ sajátosságaira reflektáló kitérővel folytatnám. Napjainkra a klasszikus (IA) nyelv, illetve a köznyelvek tanulmányozása mellett többé-kevésbé egy új részdiszciplína alakult ki az arab nyelvtudományon belül abból az igényből adódóan, hogy meg kell érteni, mi történik egyazon arab kontinuum e két végpontja, vagyis a „magas” és az „alacsony” szintek között. Régóta ismert, hogy a „magas” és „alacsony” közötti szerkezeti különbségek, amelyek történelmük során állandó adottságnak számítottak, valamikor olyan köztes, illetve kevert fajták létrejöttét és fejlődését eredményezték, amelyeket leírtak, és valószínüleg beszéltek régebben is, ugyanolyan mértékben, amennyire ma is gyakran teszik a beszélt nyelven. Különösen a premodern nyelvi helyzetekre tekintettel a szakemberek hagyományosan a „középarab” kifejezést használják ezekre a variációkra (Den Heijer 2012: 2).

Ami e kutatási szempontok és empíria történelmi összefüggéseit illeti: az arab uralom alatt a szír maronita és egyéb keresztények először a köznyelvi arab nyelvet kezdték beszélni, és nem, vagy csupán alig tudták írni 
Iványi Márton Pál: Egy látszólagos paradoxon:

a kereszténység fogalmainak arab szókészlete a máltai nyelvben

Argumentum 17 (2021), 878-894

Debreceni Egyetemi Kiadó

DOI: 10.34103/ARGUMENTUM/2021/49

A máltai nyelvészeti színtér konkrétumaira visszatérve, afféle szabályszerüség, hogy az alapvető kifejezések sémi (arab), míg az elvontabb fogalmak neolatin (olasz) eredetüek. Érdekes azonban és előbbi kvázi-regulát árnyalja, hogy a keresztény tanításokhoz kapcsolódó, absztraktabb, illetve dogmatizált fogalmakat azóta sem szorították ki (teljesen) indoeurópai (neolatin) szavak, hiszen például a modern máltai szótárakban (Aquilina 2006: 294) egyaránt szerepel a taqdis ('megszentel') és a konsagrazzjoni ('felszentel'). Fordítva is igaz, hiszen a társadalmi élet alapvető és hétköznapi fogalmai, például a vallási vezető, 'pap' jelentésü qassis mellett az egyértelmüen olasz eredetű saćerdot (Aquilina 2006: 325) is használt.

Továbbhaladva a történelmi összefüggések és feltételezések vonalán: ha az „eredeti” lakosok nagy része túlélte volna a 870-es ostromot (függetlenül attól, hogy görögül, latinul vagy éppen pun nyelven beszéltek), akkor a hódítók által bevezetett arab nyelv számos elemet felszívott volna, különösen a helyi dolgokat jelölő szavakat és kifejezéseket és helyneveket, amelyek jelentős aljréteget képeztek volna. Az ilyen rétegek hiánya általában szabály szerint mély és hirtelen változást követ, nagyon gyakran traumatikus, sőt, tragikus körülmények közepette. Al-Himyarī elbeszélése a 870-es történésekről megerősíti, hogy éppen ez vonatkoztatható Málta esetére is, mivel, mint láttuk, egyetlen korábbi nyelvnek sincsenek meggyőző nyomai, légyen szó pun, latin vagy görög nyelvröl (Brincat 2011: 39).

Noha vannak olyan elképzelések (Aquilina 1972: 73-74; Vella 2016: 84), hogy egyes fennmaradt görög eredetü müemlékek és lexikon a keresztény lakosság folytonos jelenlétéről tanúskodnának (lapsi, liti, miru stb. $)^{11}$, ám a vizsgált szavak és kifejezések abba a spekulatív irányba

azt (Samir 1982: 45). Legtöbbjük inkább az arab müveket írta át szír betűkkel, hogy könnyebben olvashatók legyenek. Az évek során kétféle arab nyelvet erősítettek meg a kéziratok: a Blau és mások által vizsgált, imént taglalt középarab kettős kódot és a köznyelvi arabot (Moukarzel 2014: 241). Sőt, a maroniták még a keresztes háborúk idején (12-13. század) is használták a szír nyelvet nemcsak a liturgikus ünneplésben, hanem a mindennapi életükben is (Jabre-Mouawad (2012: 226).

A ciprusi arabot fóként szintén Szíriából és Libanonból érkező maronita keresztények vezették be Cipruson a 7. századdal kezdődően több hullámban, egészen a 13. századig. Egyes arámi aljrétegre utaló jelek arra utalnak, hogy annak megjelenése közel állhatott az arámiról arabra való áttérés időszakához. A ciprusi szakaszban a nyelv alaposan átstrukturálódik az újgöröggel való érintkezés révén, és számos olyan tulajdonságot és korlátot szerzett, amelyek nem jellemzőek az arab nyelvre. Arab összetevője Délkelet-Anatólia, Észak-Szíria és Mezopotámia, valamint a Levante különböző területeiről és idejéből származó dialektusok ötvözete, amely egyszersmind egyedülálló betekintést kínál a keleti arab történelmi pályafutásába is (Vertseegh 2011: 536541). Jelenleg lényegében érthetetlen a szárazföldi arab nyelvet beszélők számára, és másokkal, például a témánk homlokterében álló máltaival együtt elszigetelt ,peremleges arabként” [peripheral Arabic] csoportosítható (Borg 2004: xviii-xix).

A Közel-Kelet és Észak-Afrika zsidó közösségei által beszélt úgynevezett judeo-arab középarabbal (den Heijer 2012: 11) kapcsolatban Joshua Blau megállapítja, hogy a középkori zsidók és arabok kulturális szimbiózisa általában nem az egyes zsidó és muszlim egyének, hanem a zsidó és arab társadalmi csoportok vívmánya volt. Ezért általában véve a két kultúra közötti korlátok megmaradtak. Ez az elkülönülés egyik külső jele az volt, hogy az írás tükrében is érvényre jutott. A zsidóság nagy része ugyanis, az értelmiséget leszámítva, alig tudott arab írásjeleket olvasni: mind a héber, mind az arab írásnál a héber írásukat használták. Még a muszlim szerzők müveit is átírták héber betükkel, hogy könnyebben tudják olvasni őket (Blau 1981: 35-36).

11 Eme okfejtések részint vitaképesek, részint egyes elemeikben inkább elvetendők Godfrey Wettinger (1995: 34-39) nézete alapján. Ö ugyanis szintén megállapítja, hogy noha korábban egyes máltai történészek, pl. a 17. századi Abela is, tettek kísérletet a bizánci idők állítólagos nyelvi örökségének folytonos kimutatására, olyan homályos eredetủ máltai szavak, mint a liti, litanie, lapsi, cona, miru vagy malluta, illetve helynevek alapján, mint a Wied ir-Rum, 'Róma (illetve konkrétabban: Bizánc) völgye' vagy a Bieb el Grekin (Bieb l-Gћarreqin 'Görögök völgye'), ,,a történészek visszautasítják e legendák sorozatát”. 
Iványi Márton Pál: Egy látszólagos paradoxon:

a kereszténység fogalmainak arab szókészlete a máltai nyelvben

Argumentum 17 (2021), 878-894

Debreceni Egyetemi Kiadó

DOI: 10.34103/ARGUMENTUM/2021/49

tájolnak, hogy Brincat (2011: 58) következtetésének adjunk helyt, miszerint a kései antik máltai kereszténység a beszélt nyelv tükrében nemigen maradt fenn 870 után.

E lexikon egyszersmind értelemszerüen azt is alátámasztja, hogy a keresztény vallást és hitéletet a normann időszakban már újra gyakorolták.

Arra nézve, hogy az arab időszakban beszélhetünk-e keresztény közösségröl, csakis találgatásokkal élhetünk. A máltai arab uralom történetét ugyanis jelentős ellentmondások övezik. A történész Stanley Fiorini és Horatio C. R. Vella professzorok véleménye szerint a kereszténység, amelyet Szent Pál vezetett be Máltára 60 körül, nagyon is fennmaradt az arab uralom alatt 870 és 1090 között, legalábbis Gozo szigetén (2016: 83)

Nem zárható ki, ahogy fentebb előre bocsátottam, egy, a keresztény és iszlám érák közötti éles váltás sem, ami al-Himyarī beszámolójából következne, illetve ezzel összefüggésben az sem, hogy a későbbi keresztény uralom mély gyökeret eresztett iszlamizált társadalmi struktúrákra lelt Máltán a normann berendezkedéskor.

Ilyenformán a máltai keresztény szókészlet a muszlim vallási fogalmak leszármazottja is lehet. Így a Randan ('nagyböjt') szó akár az iszlám böjti és áldozati szent hónapja, a Ramaḍān nevéböl is származhat. Hasonlóképpen, a Ghid (húsvét) gyökerei az İd al-Fiṭr ('a böjt megtörésének ünnep muszlim ünnepéig is érhetnek, a Milied ('karácsony') pedig utalhat történetesen a maulidra (IA: mawlid), vagyis Mohamed próféta születésének szintén muszlim ünnepére is. (Utóbbi példának ellentmondani látszik, hogy a muszlimok Mohamed próféta születésnapját csak jóval 1000 után kezdték intézményesíteni az egyiptomi fátimidák - Katz 2007: 2), tehát akkoriban bontakozhatott ki az iszlám világban, és elsősorban Egyiptomtól keletre, amikor a máltai uralom a XI. században már leáldozni kezdett a normann betörések hatására).

Felmerül ugyanakkor, hogy a máltai il-Gimgћa ('péntek') szó a szigeteken élő muszlimok heti gyülekezeti napjáról (IA: ğumu'a) kapta a nevét. Az is elgondolkodtató, hogy egyes keresztény fogalmak modern arab megfelelői jelentősen vagy akár teljesen eltérnek máltai megfelelőiktől, például a máltai il-Gímgћa l-Kbira (szó szerint: 'Nagypéntek') irodalmi arab ekvivalensei yawm al-ğum 'a al-hazinna 'a szomorú péntek napja' vagy al-ğum 'a al- 'azìma). Ez egyrészt alátámaszthatja az archaizálódott arabról alkotott felfogást (Kontzi 1986: 24), másrészt felveti egy muszlim epizód, vagyis az iszlám fogalmakon keresztül történő közvetítés kérdését is ennek részeként.

Természetesen a 870-es cezúra és a normann hódítás között is létrejöhettek keresztény, mégpedig arabul beszélő közösségek Máltán, akik együtt éltek a 12. század végéig még dokumentáltan a szigeten élő (Wettinger (1995: 37; Dalli 2002: 37-56) muszlim lakossággal, ami szintén a vizsgált lexikon, illetve fogalomkészlet átfedéseihez, metszeteihez vezethetett. Sőt: Nadia Jamil és Jeremy Johns (2016: 115) vonatkozó beszámolója szerint kizárólag muszlimok lakhatták a szigeteket a keresztény uralom visszatéréséig.

Számos vetélkedő elgondolás, illetve ezek kombinációi léteznek tehát. Ami bizonyos, hogy a helyi színtér nagyon erősen elarabosodott és iszlamizálódott volt, mire a normannok meghódították a szigeteket. Ugyanakkor nem lehet kizárni, hogy a muszlim közösség egyelőre tisztázatlan jellegü, bonyolult (alighanem az együttmüködés és a rivalizálás mintáit egyaránt felvonultató), ugyanakkor hosszantartó és erős nyelvi, illetve kulturális kapcsolatban állhatott a szükebb (Gozo) vagy tágabb (Szicília) értelemben vett térségi kereszténységgel.

Brincat (2011: 56) meggyőző érvelése szerint ha éppen ellenkezőleg, a kereszténységet nyelvi és kulturális vallási kölcsönhatási előzmények nélkül a kései normann időszakban, hosszú szünet után, újra bevezették volna Máltán 1127-től, amint azt a máltai történész Godfrey 
Iványi Márton Pál: Egy látszólagos paradoxon:

a kereszténység fogalmainak arab szókészlete a máltai nyelvben

Argumentum 17 (2021), 878-894

Debreceni Egyetemi Kiadó

DOI: 10.34103/ARGUMENTUM/2021/49

Wettinger (1995: 34-39) és mások (l. fentebb) is feltételezik, akkor az teljesen latin terminológia kíséretében épült volna be a szókészletbe. Ez történt azon lexémák esetében, amelyek a keresztény kultusz fejlettebb alakzatait, tárgykörét érintő elvont fogalmak (pl. virtù 'erény', sagramént 'szentség', adorazzjioni 'imádat', konfessinarju 'gyóntató') vagy a szakrális öltözékek (tonka 'tunika', spellizza 'miseing', stola 'stóla'), valamint a templomok bútorzatának és belső díszítésének referenciái (pulptu 'szószék', artal 'oltár', gandlier 'gyertyatartó' vagy tabernaclu 'szentségtartó'), amelyek egyértelmüen szicíliai vagy olasz eredetűek (vö.: Aquilina 1971: 28; Iványi 2016: 352).

Ami azt illeti, a keresztény politikai és vallási szféra bevezetésének időzítése sem tisztázott. Egyesek (pl. Brincat 2011) annak kezdeteit a 11. századra, mások (pl. Wettinger 1995) azt legkorábban 1127-re teszik. Valószínüsíthető mindenesetre, hogy a kölcsönhatások folyamatosak maradhattak ezt követően is. Charles Dalli (2002: 37-56) szerint később, a normann uralom idején minden bizonnyal a keresztény berendezkedés viszonylagos vallási türelmet gyakorolt a helyi társadalommal, legalábbis a 13. század derekáig, a muszlimok tömeges kitelepítéséig. Feltételezhetö, hogy noha sürgették a helyi társadalmat, hogy térjenek át a kereszténységre, latinosítani nem latinosították őket, megengedve, hogy továbbra is arabul beszéljenek.

\section{5 Összefoglalás}

Amilyen színes és sokrétü a máltai nyelv és történet tablója, annyira ellentmondásosak és homályosak is annak egyes aspektusai.

Egy nyelvföldrajzi paradigma rétegtani modellje a maga esetleges hézagaival együtt is segíthet megérteni annak réteges szerkezetét, ha azok egymáshoz füződő viszonyainak akkurátus, minden kétséget kizáró tagolása korszakok szerint alighanem egy, a történelmi idök ködébe vesző vállalkozás.

A szigetcsoporton a közösségi letelepedés hagyományai vitathatóan egészen a főníciaiakig érnek, ám a leginkább nyomot, időrendi sorrendben haladva, a témafelvetésünk szempontjából ezúttal közömbös angolt megelőzően a római, a bizánci görög, az arab és a normann keresztény uralom hagyott. Előbbi kettő gyakorlatilag a müemlékekre korlátozódik, utóbbi kettő a nyelv sémi magját, illetve neolatin szövetét, a.m. integráns részeit képezik.

Emlékeztetöül, Málta esetében, ha a vallási gyakorlat a bizánci időkből fennmaradt volna, különösen, ha a népesség nagy létszámú és homogén volt, akkor a liturgikus nyelv a (kelet-)római időknek megfelelően bizonyosan latin, illetve görög maradt volna, vagy legalábbis erős latin/ görög szubsztrátumot hagyott volna maga után.

Akárhogyan is áll az i.sz. első évezred második felének, illetve az ezredforduló utáni pár évszázad történelmének kérdése, a máltai arab alaprétege nyelvészeti tény. A keresztény kultuszhoz kapcsolódó arab lexikon mély gyökerezettsége, amelynek ezúttal inkább csak villanásszerü szemléltetésére vállalkoztunk a teljesség igénye nélkül, alátámasztják egy, a 9-11. századi normann idők elött és alatt létező arab nyelvü közösség eshetőségét. E szavakat a máskülönben a nyugati világ felé forduló szigetcsoport nyelve szókészletének későbbi rétegei sem tudták teljesen maguk alá gyürni, ami, ha nem is feloldhatatlan paradoxon, ám egy, a maga nemében hallatlanul izgalmas, további vizsgálódásokat igénylő és ösztönző nyelvészeti probléma. 
Iványi Márton Pál: Egy látszólagos paradoxon:

a kereszténység fogalmainak arab szókészlete a máltai nyelvben

Argumentum 17 (2021), 878-894

Debreceni Egyetemi Kiadó

DOI: $10.34103 / A R G U M E N T U M / 2021 / 49$

\section{Irodalom}

Abdelkader, R. (1977): English-Tunisian Arabic Dictionary. Washington: Peace Corps.

Agius, C. (2005): Maltese Religious Terms Of Arabic Origin. Melkite Greek Catholic Church Information Center. https://www.mliles.com/melkite/docrch2.doc

Aquilina, J. (1972): Maltese Christian Words of Arabic Origin. In: d. Galley, M. \& David R. Marshall (eds.): Proc. of Congrès D'études Des Cultures Méditerranéennes D'influence Arabo-berbère, Malta. Algír: Société Nationale D'édition Et De Diffusion, 70-74.

Aquilina, J. (2006): Concise Maltese-English Dictionary. Midsea Books.

Blau, Joshua (1981): The Emergence and Linguistic Background of JudaeoArabic. A Study of the Origins of Middle Arabic. Vol. II., Jeruzsálem: Ben-Zvi Institute.

Borg, A. \& Azzopardi-Alexander, M. (1997): Maltese. Descriptive Grammars. London: Routledge.

Borg, Alexander (2004): A Comparative Glossary of Cypriot Maronite Arabic (ArabicEnglish). Leiden: Brill. https://doi.org/10.1163/9789047413974

Brincat, J. M. (2008): Before Maltese: languages in Malta from prehistory to the byzantine age. In: Bonanno, A. \& Militello, P. (eds.): Malta in the Hybleans, the Hybleans in Malta: Malta negli Iblei, gli Iblei a Malta. Palermo: Officina di Studi Medievali, 233-244.

Brincat, J. M. (2011): Maltese and other languages. Santa Venera: Midsea Books.

Dalli, C. (2002): A Muslim society under Christian rule. In: Azzopardi, J., Cortis, T., Freller, T. \& Bugeja, L. (eds.): Melitensium amor: festschrift in honour of Dun Gwann Azzopardi. Malta : Gutenberg Press, 37-56.

Dozy, Reinhart Pieter Anne (1881): Supplément aux dictionnaires arabes, vol. 1. Leiden: E. J. Brill.

Fiorini, S. \& Vella, H. C. R. (2016): Reactions to Tristia Ex Melitogaudo: A Response. Literatūra 58 (3), 75-87. https://doi.org/10.15388/Litera.2016.3.10425

Harrell, R. S. (2004): A Dictionary of Moroccan Arabic. Harrell R. S. \& Sobelman, H. (eds.) Washington, DC: Georgetown University Press.

den Heijer, Johannes (2012): Introduction: Middle and Mixed Arabic, a New Trend in Arabic Studies. In: Zack, Liesbeth \& Schippers, Arie (eds.): Middle Arabic and Mixed Arabic Diachrony and Synchrony. Leiden: Brill, 64. 1-25. https://doi.org/10.1163/9789004228047_002

Iványi, M. P. (2016): Máltai: arab nyelvjárás és/vagy „nyelvötvözet”? Nyelvtudományi Közlemények 112, 339-364. https://doi.org/10.15776/NyK.2016.112.14

Jabre-Mouawad, Ray (2012): Maronites and the Garshuni script. Parole de l'Orient 37, 223 240.

Jamil, N. \& Johns, J. (2016): A New Latin-Arabic Document from Norman Sicily. (November 595 h/1198ce). In: Pomerantz, M. A. \& Shahin, Aram (eds.): The Heritage of Arabo-Islamic Learning. https://doi.org/10.1163/9789004307469_007

Katz, Marion Holmes (2007): The Birth of The Prophet Muhammad: Devotional Piety in Sunni Islam. Culture and Civilization in the Middle East. London: Routledge.

Kontzi, R. (1986): The Maltese and the Arabic dialects: an approach from linguistic geography. Journal of Maltese Studies, 16, 22-44.

Moukarzel, Joseph (2014): Maronite Garshuni Texts: on their Evolution, Characteristics, and Function. Hugoye: Journal of Syriac Studies, Vol. 17.2, 237-262.

https://doi.org/10.31826/hug-2015-170114 
Iványi Márton Pál: Egy látszólagos paradoxon:

a kereszténység fogalmainak arab szókészlete a máltai nyelvben

Argumentum 17 (2021), 878-894

Debreceni Egyetemi Kiadó

DOI: $10.34103 / A R G U M E N T U M / 2021 / 49$

Samir, Khalil Samir (1982): La tradition arabe chrétienne. État de la question, problèmes et besoins. In: Samir, K. S. (ed.): Actes du premier congrès international d'études arabes chrétiennes (Goslar, septembre 1980). (OCA 218), Róma.

Scarrow, S. (2015 [2012]): Kard és handzsár. Debrecen: Gold Book.

Trimble, L. P. (1973): Some Linguistic Comments on Religious Terms in Maltese. Journal of Maltese Studies 9, 59-67.

Versteegh, Kees (2011): Encyclopedia of Arabic Language and Linguistics. Leiden: Brill.

Wehr, H. (1976): A Dictionary of Modern Written Arabic. Ed. by. J Milton Cowan. Third Edition. Ithaca, N.Y.: Spoken Language Services Inc.

Dr. Iványi Márton Pál

Budapesti Corvinus Egyetem, Társadalomtudományi Kar

Társadalmi Kommunikáció Doktori Iskola

H-1093 Budapest

Fővám tér 8.

martonpivanyi@gmail.com 